\title{
出水イベントに伴う福島新田川河口周辺海域 における懸濁態放射性核種の海洋分散について
}

\author{
山西 挀文 1 ・ 内山 雄介 ${ }^{2}$ ・岩崎 理樹 3 ・清水 康行 $4 \cdot$ \\ 津旨 大輔 5 ・ 三角 和弘 5 ・恩田 裕一 6

\begin{abstract}
1 正会員 中日本高速道路株式会社（广460-0003 名古屋市中区錦2-18-19） E-mail: 37ct57@gmail.com
2 正会員 神戸大学教授大学院工学研究科市民工学専攻（广657-8501 神戸市灘区六甲台町1-1）

3 正会員 (国研) 寒地土木研究所寒地水圈研究グループ（テ062-8602 札幌市豊平区平岸1条3-1-34）

4 正会員 北海道大学教授大学院工学研究院（ T060-8628 札幌市北区北13条西8丁目）

5 正会員 (一財) 電力中央研究所環境科学研究所（

6 正会員 筑波大学教授アイソトープ環境動態研究センター（テ305-8577 茨城県つくば市天王台1-1-1）
\end{abstract}

\begin{abstract}
二級河川福島県新田川の流域には福島原発事故直後に大量の $137 \mathrm{Cs}$ が大気経由で沈着し，河道内には高濃 度の ${ }^{137} \mathrm{Cs}$ が吸着した土砂が堆積していた. 本研究では, 荒天・出水イベントによる事故直後の新田川河口 および沿岸域における陸域起源の137Csインベントリを定量的に評価するために，iRIC-Nays2DHをベースと した平面2次元河道モデルを用いた高出水時の河川流量および粒径別土砂流入フラックスの計算結果を用 いて, 同河口域における新田川由来の懸濁態137 $\mathrm{Cs}$ の海洋分散解析を行った．河口域観測結果等も併せて検 討した結果， 2011年5月末の大出水時に新田川から流入した㲘濁態137Csは, 約一ヶ月経過しても70\%程度 が河口付近に残存していること, 流入した懸濁態 ${ }^{137} \mathrm{Cs}$ は再㲘濁と再輸送を繰り返しながら数ヶ月以上の長 い時間スケールで再分配され，長期的には河口域から散冕することが示唆された.
\end{abstract}

Key Words : suspended radionuclide, cesium 137, fluvial influence, sediment transport model, ROMS

\section{1. はじめに}

福島第一原子力発電所から海洋へ漏洩した放射性核種 の分散評価に対して, 溶存態 ${ }^{137} \mathrm{Cs}$ の動態解析モデルに 代表される様々な輸送・分散モデルが提案され, 海洋污 染の実態解明が進展してきた。一方，大気中に放出され 陸域に沈着した ${ }^{137} \mathrm{Cs}$ は鉱物系粒子に強く吸着し, 水文 過程を経て河道内に堆積, あるいは河口を通じて海洋に 流入し続けている。 したがって，陸域から海域に至る放 射性核種の輸送経路として河川は極めて重要であり，陸 域-海域間の移行過程を定量化的に評価するためにこの プロセスを精緻に解析することが強く求めれられている.

このような要請に対して, 著者ら 1)（以下前報）は, 波浪の影響を考慮したマルチクラス懸濁質輸送モデルを 開発し，河川由来土砂およびそれらに吸着した懸濁態放 射性核種の福島沿岸域での分散評価などを行った。前報 では河川から海洋への流入土砂量として, 河川流量から 経験的にフラックスを推定する全国平均 $L^{\prime} Q^{\prime}$ 式2) を用い て評価した. しかしながら，これらの推定值には河川に よっては極めて大きな誤差を有する場合があった．特に, 海洋への土砂供給およびその分散プロセスに非常に大き
な影響を与える大規模出水時において領域内のほぼ全て の河川で大幅に過小評価する傾向が見られ，懸濁態放射 性核種の陸-海移行過程について定量的な評価を行うた めには改善が必要であることが判明した。

一方, 福島第一原発から約 $24 \mathrm{~km}$ 北の福島県南相馬市 原町に河口を有寸る二級河川である新田川は，原発事故 により放出された放射性核種の動態に関する学際的研究

（ISET-R）において重要な研究対象領域と位置づけられ, 流域，河道および河口域で様々な観測が行われている. 新田川は阿武隈川などと比べると流量は小さいものの, その流域には事故直後に大気由来の ${ }^{137} \mathrm{Cs}$ が沈着し, 河道 内には高濃度の ${ }^{137} \mathrm{Cs}$ が吸着した土砂が堆積していたこと が報告されている33. 特に大規模出水時にはそれらが海 洋一と断続的に流入することにより, 沿岸域の海洋環境 に大きく関与しているものと考えられる.

そこで本研究では, 前報1 で用いた福島県沿岸域マル チクラス土砂輸送モデルに対してもう一段階のダウンス ケーリングを行い, 新田川河口域およびその周辺海域を 対象とした高解像度海洋流動・䀣濁質輸送モデルを構築 乙, 前報同様に, 䀣濁質粒子比表面積と懸濁態 ${ }^{137} \mathrm{CS}$ 濃度 の関係式を組み込むことで，河口から供給される土砂と 


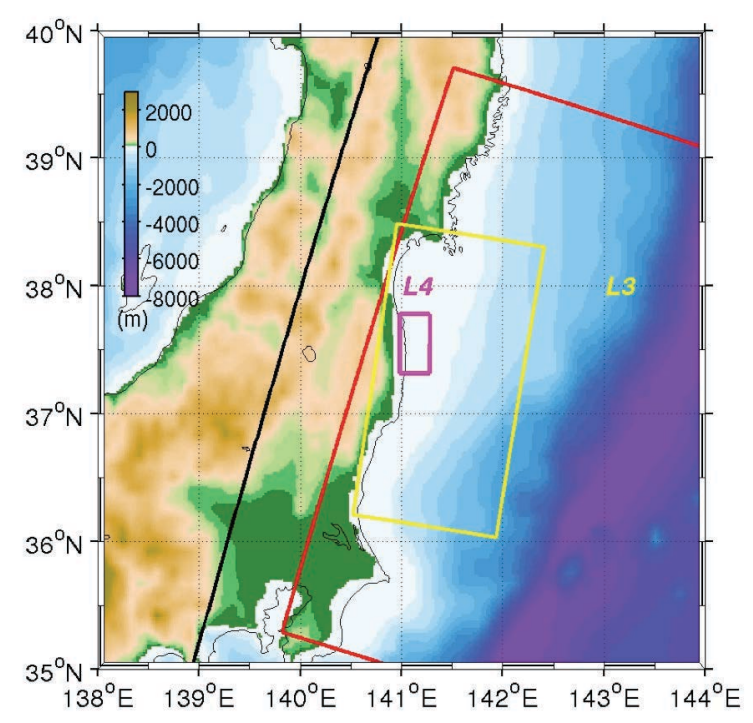

図-1 4 段ネスト ROMS モデルの計算領域. 黒枠 : ROMSL1，赤枠：ROMS-L2，黄枠 : ROMS-L3，マゼンダ枠： ROMS-L4 の計算領域を表す．カラー : 水深 $(\mathrm{m})$.

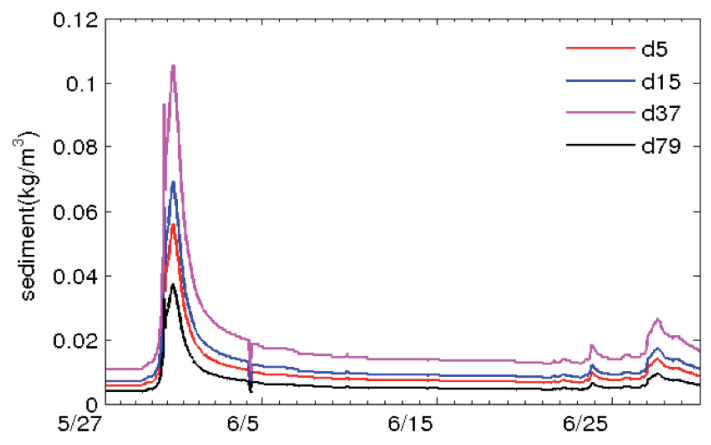

図-2 新田川からの各粒径流出土砂濃度 $\left(\mathrm{kg} / \mathrm{m}^{3}\right)$.

懸濁態 ${ }^{137} \mathrm{Cs}$ の海洋分散に関する同時評価を行った。荒 天・出水イベントによる新田川由来の懸濁態放射性核種 の海洋への影響をより精緻に評価するために，iRICNays2DHをベースとした平面2次元河川流・河床変動モ デルを用いて新田川からの高出水時の河川流量および粒 径別土砂流入フラックスを計算した．対象とする出水イ ベントは，原発事故後初めての大規模出水である2011 年5月末の発達性低気圧接近時の出水であり, 出水時を 含む約1ヶ月間にわたって新田川から流入した懸濁態放 射性核種の海洋での分散解析を行った。

\section{2. 解析モデルの概要}

前報1)で開発した，JCOPE2再解析值を境界条件とする 福島県沿岸域を対象とした3段ネスト海洋ダウンスケー リングモデルの最内側モデルであるROMS-L3（水平解像 度 $250 \mathrm{~m}$ ）の結果を用い, さらにもう一段階のネスティ ングを施すことにより，新田川河口域を対象とした水平 解像度50 mのROMS-L4モデルを構築した（図-1，表-1）。 L4モデルでは，河川モデルの計算結果に基づいて active
表-1 新田川河口域モデル（ROMS-L4）の計算条件

\begin{tabular}{|c|c|c|c|c|c|}
\hline \multicolumn{2}{|c|}{ 計算期間 } & \multicolumn{4}{|c|}{2011 年 5 月 26 日～2011年 6 月 30 日 } \\
\hline \multicolumn{2}{|c|}{ 解析期間 } & \multicolumn{4}{|c|}{2011 年 5 月 27 日～2011年 6 月 30 日 } \\
\hline \multicolumn{2}{|c|}{ 格子数 } & \multicolumn{4}{|c|}{$1,024 \times 512 \times 32$ 層, 水平解像度 : $50 \mathrm{~m}$} \\
\hline \multicolumn{2}{|c|}{ 境界条件 } & \multicolumn{4}{|c|}{ ROMS-L3（三時間平均值）を線形補間 } \\
\hline \multicolumn{2}{|c|}{ 海上風 } & \multicolumn{4}{|c|}{ JMAGPV-MSM（一時間值） } \\
\hline \multicolumn{2}{|c|}{ 海面フラックス } & \multicolumn{4}{|c|}{ NOAACOADS（月平均気候值） } \\
\hline \multicolumn{2}{|c|}{ 海表面温度 } & \multicolumn{4}{|c|}{ AVHRR Pathfinder（月平均気候值） } \\
\hline \multicolumn{2}{|c|}{ 河川流量 } & \multicolumn{4}{|c|}{$\begin{array}{l}\text { HYDREEMS 推算值（日平均値），新田川 } \\
\text { のみ iRIC-Nays2DH 推定值（1 時間値） }\end{array}$} \\
\hline \multicolumn{2}{|c|}{ 海底地形 } & \multicolumn{4}{|c|}{ 内閣府中央防災会議・地形データ } \\
\hline \multicolumn{2}{|l|}{ 波浪 } & \multicolumn{4}{|c|}{ SWAN 推算值（三時間平均値） } \\
\hline \multicolumn{6}{|c|}{ 表-2 マルチクラス土砂モデルパラメータ } \\
\hline class & $\begin{array}{c}d \\
(\mu \mathrm{m}) \\
\end{array}$ & $\begin{array}{c}\rho_{s} \\
\left(\mathrm{~kg} / \mathrm{m}^{3}\right) \\
\end{array}$ & $\begin{array}{c}w_{S} \\
(\mathrm{~mm} / \mathrm{s}) \\
\end{array}$ & $\begin{array}{c}E_{u} \\
\left(\mathrm{~kg} / \mathrm{m}^{2} \mathrm{~s}\right) \\
\end{array}$ & $\begin{array}{c}\tau_{c r} \\
\left(\mathrm{~N} / \mathrm{m}^{2}\right) \\
\end{array}$ \\
\hline d5 & 5.43 & 2650 & 0.026 & $1.0 \times 10^{-4}$ & 0.012 \\
\hline d15 & 15.26 & 2650 & 0.209 & $1.0 \times 10^{-4}$ & 0.035 \\
\hline d37 & 36.80 & 2650 & 1.212 & $1.0 \times 10^{-4}$ & 0.083 \\
\hline d79 & 79.49 & 2650 & 5.478 & $1.0 \times 10^{-4}$ & 0.159 \\
\hline
\end{tabular}

ただし, $d$ : 中央粒径, $\rho_{s}$ : 土粒子密度, $w_{s}$ : 沈降速度, $E_{u}$ : 再懸濁率， $\tau_{c r}$ : 限界せん断応力. 空隙率 : $\lambda=0.4$ (一 定），交換層の厚さ： $\delta_{a}=3 \mathrm{~mm}$; 初期基層の厚さ: $10 \mathrm{~m}$.

トレーサとして粒径 $5 \mu \mathrm{m} ， 15 \mu \mathrm{m} ， 37 \mu \mathrm{m} ， 79 \mu \mathrm{m}$ (それ ぞれd5～d79 と呼称）の4画分の多粒径土砂を考慮した

(表-2) . 気象庁GPV-CWMにSWANをネスティングした 波浪推算モデルにより平面波浪場を求め, 再䀣濁に関連 する底面せん断応力は，波-流れ共存場に対するモデル で評価した．４4領域内に河口を有する6本の河川（いず れも二級河川）のうち，新田川を除く5河川に対しては 電中研 HYDREEMSモデル4)による日平均淡水フラックス 推算值を与えた。陸域からの土砂流入は新田川について のみ考慮することとし，新田川の淡水流量および流入浮 遊土砂量は河川モデルから得られる下流端での 1 時間毎 の計算結果を与えた（図-2）。流入土砂に吸着した懸濁 態137 $\mathrm{Cs}$ 量は，阿武隈川河口での土粒子の比表面積との関 係式5 を用いて評価した. なお，モデル内では掃流砂， 溶存態 ${ }^{137} \mathrm{Cs}$ と懸濁態 ${ }^{137} \mathrm{Cs}$ 間の相変化, 土砂への吸脱着の 等は考慮していない．2011年5月末の台風接近時の出水 イベントを解析対象とし，計算期間は2011年5月26日か ら6月末までの約1ヶ月間とした. モデルのさらなる詳 細についてはBlaasらわおよび前報1を参照されたい。

\section{3. 新田川からの流出土砂の海洋分散パターン}

新田川から流入した土砂の海洋分散過程を時空間的に 把握するために, 粒径が最も小さく輸送されやすい d5 画分の海洋表層および底層での濃度のスナップショット を図-3，図-4に示寸．荒天イベントおよび大規模出水前 の 5/27（計算開始から 1 日後）における表層濃度分布 
$\begin{array}{llll}\text { (a) 27-MAY,12:00,UTC } & \text { (b) 31-MAY,11:00,UTC } & \text { (c) 1-JUN,19:00,UTC } & \text { (d) 10-JUN,01:00,UTC }\end{array}$

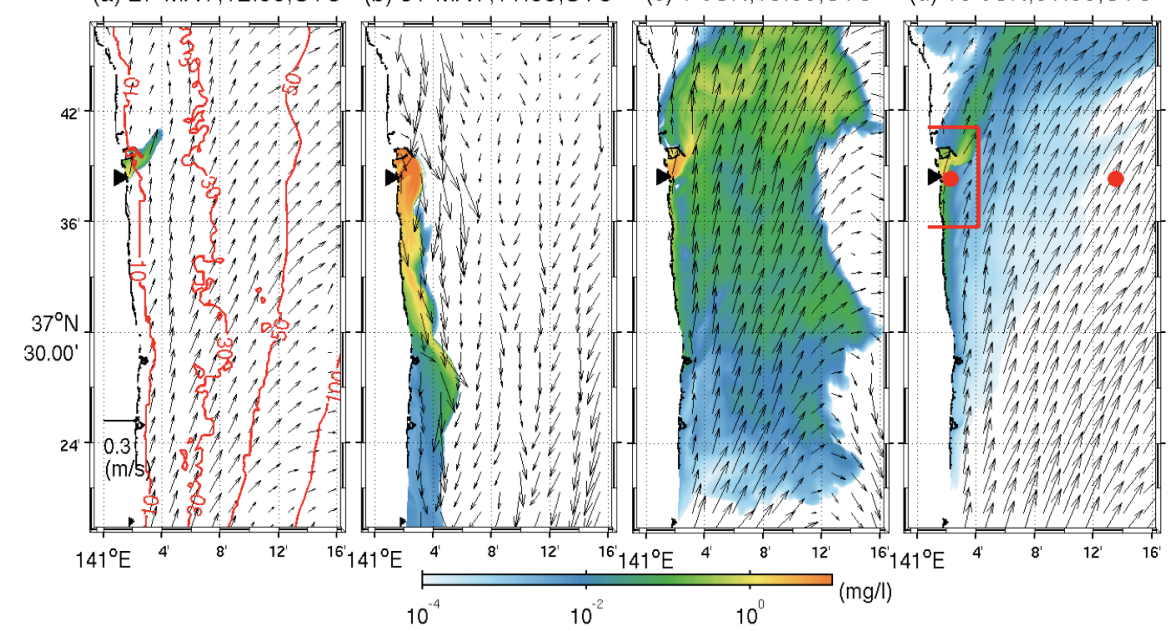

図-3 d5 画分䀣濁物の海洋表層濃度（カラー， mg/L）と流速ベクトルのスナップショット.・は新田川の河口位置，(a)の赤コ ンターは水深 $(\mathrm{m}), \quad$ (d) の赤枠と赤点は後の解析で用いる検查断面および検査点.

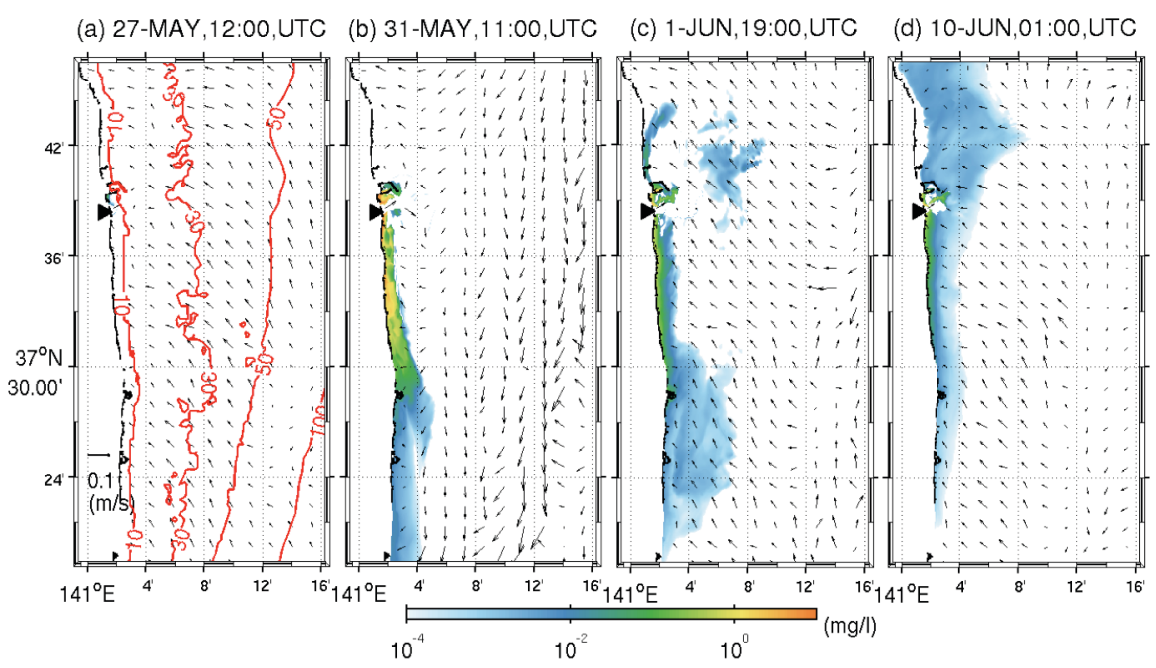

図-4＼cjkstart図-3 と同じ．ただし底層における $\mathrm{d} 5$ 画分懸濁物濃度（カラー， $\mathrm{mg} / \mathrm{L} ）$ と流速ベクトル.

（図-3 (a)）を見ると，岸近傍に発達する北上流によっ て北東方向へと土砂が輸送されている. 新田川河口北部 約 $2.6 \mathrm{~km}$ 地点の海岸には原町火力発電所が立地してい るが，その南部方波堤によって北向き土砂輸送が阻害さ れ，土砂は岸に沿って真北に輸送されることはなく，北 東方向へと輸送される，同時刻における海洋底層では

（図-4 (a)），河口前面に表層からの淡水流出を補償す るような向岸流が発生して沖方向への土砂輸送が抑制さ れ，南防波堤に沿うように土砂濃度が分布している.

一方，大規模出水直後の 5/31 の表層（図-3(b)）では 南下流が発達し, 土砂は岸に沿って南へ輸送される. こ のとき発生した強い南向き風に伴う岸向きエクマン輸送 によって（図-5，図-6），表層および底層土砂（図-4(b)） は岸に張り付いた形で南下寸る. 特に底層土砂は水深 1 $0 \mathrm{~m}$ 以浅に輸送が集中している，なお，北緯 37030 付近 で土砂濃度が岸から剥離して沖方向へ膨らみながら南下 を続けているが，これは沖に凸な沿岸地形と，凸部頂点 に位置する請戸漁港防波堤（河口から南に約 $17 \mathrm{~km}$ ，原 発から北に約 $7 \mathrm{~km}$ ）の影響を受けたためである. その
32 時間後に相当する低気圧通過後の 6/1 (図-3 (c), 図4 (c)）には流れが一気に北へと転じ，岸向きエクマン輸 送も沖向きに変化し，土砂は沖方向一広く分散しながら 北東方向へと輸送される. 低気圧通過から十分時間が経 過すると（図-3 (d), 図-4 (d)）, 平均的には表層では北 東，底層では北西に向かう流れが生じ，土砂は主に表層 に集中した形で沖方向へと輸送されている.

\section{4. 新田川河口周辺海域での流動場の形成機構}

福島県沖の陸棚域での海水の流速変動は，海上風の沿 岸方向成分によって生じる陸棚波の影響を強く受け，周 期的流速変動は自由陸棚波の第 2, 第 3 モードと密接に 関連していることが知られている 8)。2011 年春期の福 島県沖陸棚域における流速変動に対して, 著者ら9も同 様の結論を導いている．同じ福島沖陸棚上にある新田川 河口周辺海域の流動や土砂分散も，同様に海上風の影響 を強く受けて形成されている可能性が高い，そこで，ク ロススペクトル解析により流動変動機構を評価する. 


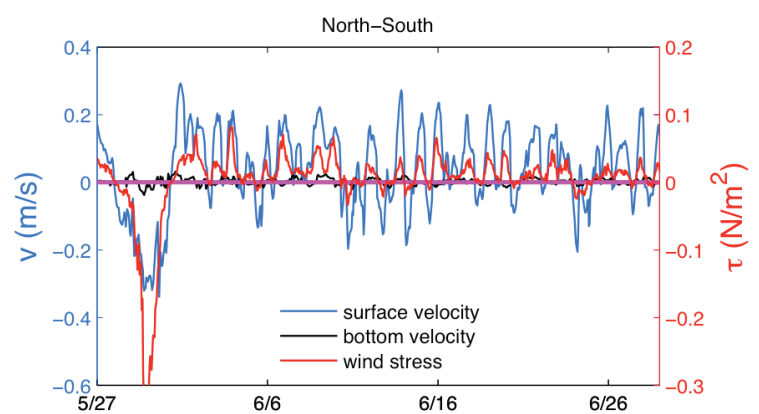

図-5 新田川河口沖 $1 \mathrm{~km}$ での北向き風応力 $\tau$ （赤），北 向き海表面流速（青）と海底直上流速（黒）.

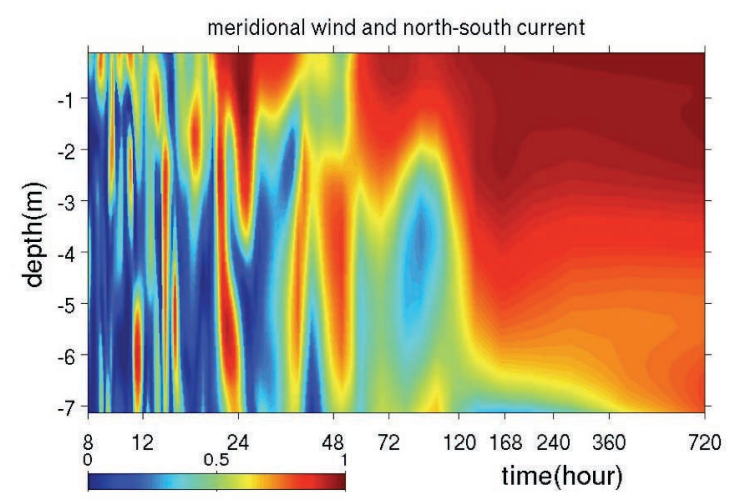

図-7 新田川河口沖 $1 \mathrm{~km}$ での北向き風応力と北向き海表 面流速のコヒーレンスの水深分布.

新田川河口 $1 \mathrm{~km}$ 地点（水深約 $7.2 \mathrm{~m}$, 図-3 (d) 左側の 赤点位置）での海表面流速・底層流速・海上風応力の南 北成分の時系列（図-5）を見ると，5/27〜6/1 の出水・ 荒天イベント時に表層では強い南下流が発達寸るのに対 して，底層の流れに大きな変化が見られない，平常時は 表層，底層流速はともに平均的に北上傾向を示し，風応 力変動に追従して変動している．同地点での東西成分の 時系列（図-6）を見ると，期間全体を通して海表面流速 は概ね東向きであるのに対し，底層流速は概ね西向きで ある.これは，北東向き表層流に伴い沖方向へ輸送され る海水に対する補償流が底層付近で生じたためである. なお，平常時の風応力は平均的に北西方向であり，解析 期間中はイベント時を除き，穏やかな北西向き風が卓越 していたことが分かる.

新田川沖 $1 \mathrm{~km}$ 地点での流速南北成分と海上風南北成 分とのコヒーレンスの水深分布（図-7）を見ると，表層 付近ではほぼ全周期帯において高い相関を示すが，底層 に近づくつれて相関が低下し, 海底付近 (水深 $7 \mathrm{~m}$ 程度) では日周期を中心とした高周波帯を除くと海上風との相 関は半減している．東西成分同士のコヒーレンス（図-8) には，日周期や 36 時間周期辺りで海表面および海底付 近にやや高い相関が見られるが，南北成分と比較すると 全体的な相関は著しく小さい，以上のことから，本河口 海域での沿岸方向（南北）流動は，周期数日以上の長周 期帯において海上風の南北成分と非常に強い相関を示し,

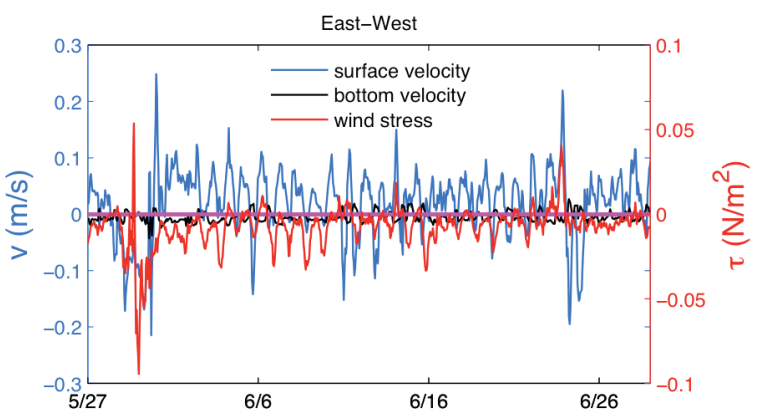

図-6 図-5 と同じ. ただし，東向き風応力と東向き流速.

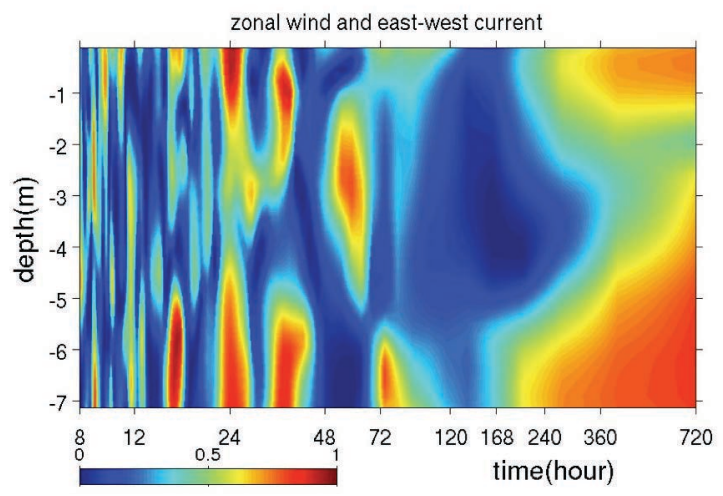

図-8 図-7と同じ。ただし，東向き風応力と東向き海表面 流速のコヒーレンス水深分布.

陸棚波的な挙動が卓越することが明らかとなった。また， 3 章で検討したように，期間中の風向変動に伴うエクマ ン輸送の方向変化に伴い，イベント時に卓越する南向き 海上風と，平常時の北寄り風によって岸沖方向に非対称 な南北方向土砂輸送が生じたものと解釈される.

\section{5. 新田川から流出した懸濁態 ${ }^{137} \mathrm{Cs}$ の分散解析}

河口から放出された懸濁態137 $\mathrm{Cs}$ 量がどの程度河口域に 残留するのかについて定量的に検討寸る。ここでは，前 報1) と同様に，河川流入土砂に吸着した懸濁態 ${ }^{137} \mathrm{Cs}$ 量と 土粒子の比表面積との関係式5)を用いて懸濁態137CS輸送 量を評価した。2011年5/27～6/30の期間にわたって新 田川から流入した懸濁態137Cs（図-9 (a)）と土砂の堆積 量（図-9 (b)）の総量を見ると，流入した土砂は概㱛河 口付近や岸近傍に堆積しており，水深30 mより深い領 域にはほとんど輸送されておらず， ${ }^{137} \mathrm{Cs}$ 堆積量も土砂堆 積量と同様な分布を示していることが分かる.

\section{(1) フラックス収支解析}

次に, 新田川から流入した土砂の海洋での輸送方向・ 分散傾向を評価するために, 図-3(d) の赤枠での断面フ ラックス収支解析を行った。検查線は新田川河口から南 北および沖にそれぞれ $5 \mathrm{~km}$ の位置に設定した．任意の 時刻 $t$ まで時間積分された累積通過フラックス $Q$ および 
(a) $\mathrm{Cs} 137\left(\mathrm{~Bq} / \mathrm{m}^{2}\right):$ 30-Jun-2011, 12:00, UTC
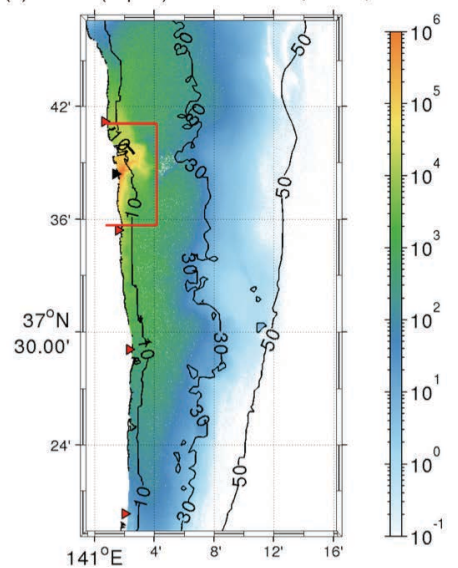

(b) sediment deposition $\left(\mathrm{kg} / \mathrm{m}^{2}\right)$
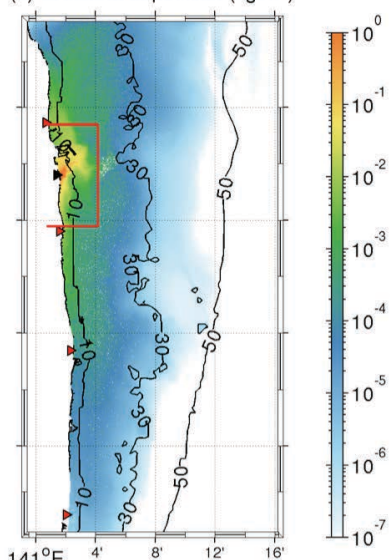

図-9 (a) 新田川から流入した土砂の海底堆積量分布（全 4 画分 の合計, $\mathrm{kg} / \mathrm{m}^{2}$ ) , (b) それに吸着した懸濁態 $137 \mathrm{Cs}$ インベン トリ $\left(\mathrm{Bq} / \mathrm{m}^{2}\right)$. コンターは水深 $(\mathrm{m}) .5 / 27 \sim 6 / 30$ の累積值.

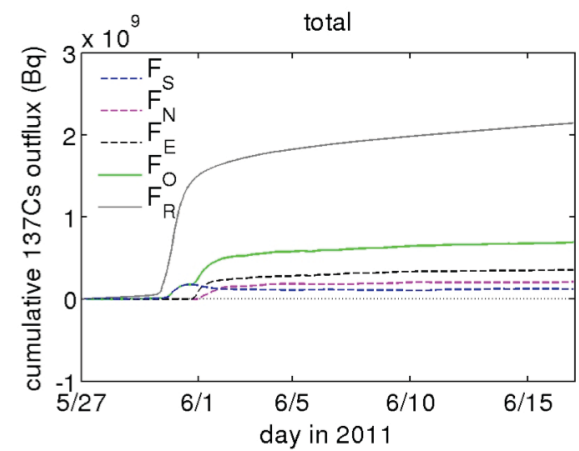

図-10 各断面を通過した累積䀣濁態 ${ }^{137} \mathrm{Cs}$ フラックス. 図-

3 (d) の赤枠内から出る方向を正と定義). 青 $F_{S}$ : 南側, マゼンダ $F_{N}$ : 北側, 黒 $F_{E}$ : 東側検査断面, 緑 $F_{O}$ : 上記 3 断面からの流出量の和，グレー $F_{R}:$ 新 田川からの流入量。

その断面積分值である断面フラックス $F$ は，断面法線方 向流速を $u_{n}$ ，濃度を $c$ として次式のように定義される.

$$
Q(\boldsymbol{x}, t)=\int_{0}^{t} c u_{n} d t ; F(t)=\int_{A} Q d A
$$

ただし， $\boldsymbol{x}$ : 任意の空間座標， $A$ : 断面積である.

懸濁態 ${ }^{137} \mathrm{Cs}$ の各断面累積通過フラックス $F($ 図-10)

は，5 月末の大規模出水直後は南下流の影響のためまず 南断面を通過する. 次いで 6 月初頭に北向きに流れが 転じると，南断面累積通過量 $F_{S}$ は減少（すなわち北向 き:負のフラックスが発生) し，一旦南断面よりも南へ 輸送された土砂が再び検査領域内（新田川河口前面海域） に戻ることが確認される．検查領域内に再流入したフラ ックスは, 出水直後に南方向へと輸送されたフラックス の 3 割程度であり，6/11 までは継続的に漸減，つまり 領域内一戻る傾向が見られる. 6 月初頭からは沿岸に発 達する北上流と原町発電所防波堤によって生じた沖向き 流れの影響を受けて（図-3），北および東側断面での通 過フラックスが生じている.6/17 時点での新田川から 海洋へと流入した d5 画分は約 $8.3 \times 10^{5} \mathrm{~kg}$ であったのに 対して, 各断面から領域外に出た $\mathrm{d} 5$ 画分はその約半分 (a) 30-MAY, 10:00,UTC (b) 10-JUNE,01:00,UTC

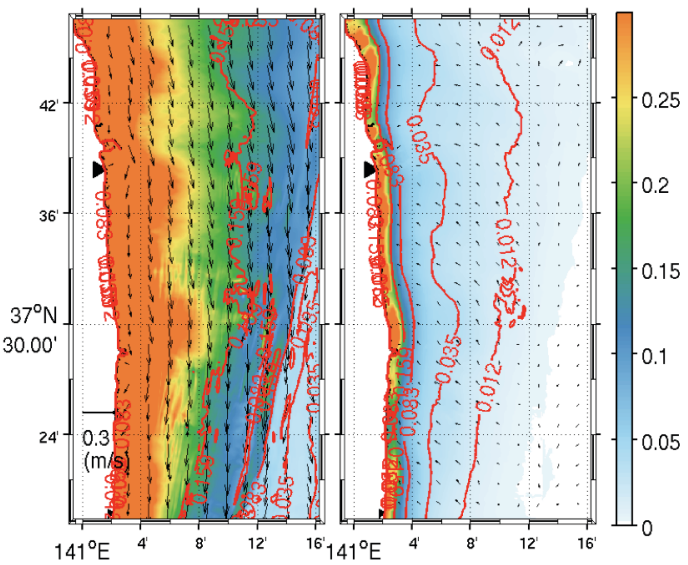

図-11 (a) 荒天時および (b) 平穏時における底面せん断 応力 (カラー, $\mathrm{N} / \mathrm{m}^{2}$ ) . コンターは各土砂画分の 限界せん断応力. ベクトルは底層流速 $(\mathrm{m} / \mathrm{s})$.

表-3 新田川からの粒径毎の流出土砂量および各断面にお ける計算開始から累積土砂通過量 $(\mathrm{kg})$ ，累積懸濁 態 ${ }^{137} \mathrm{Cs}$ 通過量 $(\mathrm{Bq})$ ．積分は 5/27〜 6/17.

\begin{tabular}{ccccc}
\hline class & $\begin{array}{c}F_{O} \\
\text { (sediment) }\end{array}$ & $\begin{array}{c}F_{R} \\
\text { (sediment) }\end{array}$ & $\begin{array}{c}F_{O} \\
(137 \mathrm{Cs})\end{array}$ & $\begin{array}{c}F_{R} \\
(137 \mathrm{Cs})\end{array}$ \\
\hline \hline $\mathrm{d} 5$ & $4.13 \times 10^{5}$ & $8.26 \times 10^{5}$ & $6.62 \times 10^{8}$ & $1.32 \times 10^{9}$ \\
$\mathrm{~d} 15$ & $6.15 \times 10^{4}$ & $1.06 \times 10^{6}$ & $3.00 \times 10^{7}$ & $5.00 \times 10^{8}$ \\
$\mathrm{~d} 37$ & 3.68 & $1.57 \times 10^{6}$ & $6.53 \times 10^{2}$ & $2.77 \times 10^{8}$ \\
$\mathrm{~d} 79$ & 0.18 & $5.53 \times 10^{5}$ & $1.35 \times 10^{1}$ & $4.04 \times 10^{7}$ \\
\hline total & $4.74 \times 10^{5}$ & $3.97 \times 10^{6}$ & $6.92 \times 10^{8}$ & $2.14 \times 10^{9}$ \\
\hline
\end{tabular}

の $4.1 \times 10^{5} \mathrm{~kg}$ であった（表-3）。また, d15 画分の検査 領域外一の流出は河川から流入した土砂量の $6 \%$ 程度と なり, d37, d79 画分においては領域外にはほぼ完全に 流出しない結果となった． 新田川からの懸濁態 ${ }^{137} \mathrm{Cs}$ 総 流入フラックスは約 $2.1 \mathrm{GBq}$ であり, ボックス外へと流 出したのはその 3 割の約 $0.7 \mathrm{GBq}$ であった。ささらにこ の流出量の $96 \%$ d 5 画分が占めることが分かった.

\section{(2) 堆積土砂の再分配の可能性}

以上のように, 2011 年 5 月末の大規模出水時に新田 川から海洋へ流入した懸濁態 ${ }^{137} \mathrm{Cs}$ は, 出水から 20 日後 の 6/17 時点では約 7 割が河口付近に残留していた。し かしながら，荒天時および平穏時における解析領域内の 底面せん断応力分布（図-11）を見ると，荒天時では岸 から沖合約 $10 \mathrm{~km}$ に至るまでの広い領域において, d79 画分の限界せん断応力を超える非常に強い底面せん断応 力が生じている．また，解析期間中最も底面せん断応力 が小さかった 6/10 でも，沖合約 $5 \mathrm{~km}$ 付近まで $\mathrm{d} 15$ の 限界せん断応力を上回っている. したがって, 河口前面 海域（検查領域）内では土砂の再䀣濁が活発に発生して おり，特に，懸濁態 ${ }^{137} \mathrm{Cs}$ の大半を構成する $\mathrm{d} 5$ 画分は常 に再懸濁していたことが分かる. 2013 年 10 月 31 日に 行われた河口域調査によると, 新田川河口前面海域の海 
底では岩盤が露出しており，土砂の堆積はごくわずかで あった（前報 L3 モデルの結果 ${ }^{1}$ とも整合的）。これら を総合的に勘案すると, 新田川から流入した懸濁態 ${ }^{137} \mathrm{Cs}$ は, 再䀣濁と輸送を繰り返しながら, 数ヶ月以上 の長い時間スケールで沿岸方向に再分配され，長期的に は河口域前面からは散逸する傾向にあると考えられる。

\section{6. おわりに}

2011年5月 27日の大規模出水以降に新田川から流入し た土砂およびそれらに吸着した懸濁態 ${ }^{137} \mathrm{Cs}$ の沿岸域への 影響について，4段ネスト波浪・流動・土砂輸送カップ リングモデルを用いて解析した. 短期的には流入土砂・ 瞅濁態 ${ }^{137} \mathrm{Cs}$ の約7割は河口付近や岸近傍に堆積し，水深 $30 \mathrm{~m}$ 以深にはほとんど輸送されない. 新田川河口域の 表層流動は主に海上風の南北成分によって駆動されてお り，海表面付近では主に北東方向の流れ，海底付近では その補償流として北西方向への流れが卓越する. 出水時 には低気圧に伴う南向き風の影響を受けて岸近傍に強い 南下流が発達し, 流入土砂の大半は南方向へと輸送され る. その後は一転して北上流が卓越し，さらに新田川北 部の原町発電所防波堤やエクマン輸送に伴う沖向き流れ の影響を受け，北東方向輸送が支配的になる. 河川から の流入土砂は一ヶ月未満の短い期間ではその大半が河口 付近に残留したが，河口海域は細粒土砂に対して常に再 懸濁が生じ得る物理環境になっており，長期的には土砂 および䀣濁態 $137 \mathrm{Cs}$ は沿岸方向へ輸送されて河口付近から は散逸していくものと推察された.

謝辞 : 本研究は科研費補助金（15H00977，15H04049） の援助を受けた。また，河川土砂供給量の評価方法につ いて, 二瓶泰雄・東京理科大学教授に教示いただいた. ここに記して深甚なる謝意を表します。

\section{参考文献}

1) 山西玩文, 内山雄介, 津旨大輔, 三角和弘: 統合型河 川・浅海域土砂輸送モデルを用いた河川由来懸濁態放射 性核種の海洋分散解析，土木学会論文集B2（海岸工学）, Vol.71, No.2, pp.I_565-I_570, 2015.

2) 武川一樹, 二瓶泰雄 : 日本の河川における浮遊土砂輸送 量と流量の相関関係, 土木学会論文集B2 (海岸工学), Vol.69, No.2, pp.I_1221-I_1225, 2013.

3) Nagao, S., Kanamori, M., Ochiai, S., Inoue, M., Yamamoto, M.: Migration behavior of ${ }^{134} \mathrm{Cs}$ and ${ }^{137} \mathrm{Cs}$ in the Niida River water in Fukushima Prefecture, Japan during 2011-2012. J. Radioanalytical and Nuclear Chemistry, Vol. 303(2), pp. 1617-1621, 2015.

4) 豊田康嗣, 平口博丸, 杉本聡一郎, 橋本篤 : 気象予測乇 デルと連携した出水予測手法の開発, http://criepi. denken.or.jp/jp/kenkikaku/report/detail/N08058.html, 2009.

5) 恩田裕一：森林および河川における放射線の長期モ ニタリングと放射性物質の移動との関連, http://fukushima.jaea.go.jp/initiatives/cat01/pdf1402 /data_07.pdf, 2014, 参照 2016-07-06.

6) Misumi, K., D. Tsumune, T. Tsubono, Y. Tateda, M. Aoyama, T. Kobayashi and K. Hirose: Factors controlling the spatiotemporal variation of ${ }^{137} \mathrm{Cs}$ in seabed sediment off the Fukushima coast: implications from numerical simulations, J. Env. Radioact., Vol. 136, pp. 218228, 2014.

7) Blaas, M., C. Dong, P. Marchesiello, J. C. McWilliams and K. Stolzenbach: Sediment transport modeling on Southern Californian shelves: A ROMS case study, Cont. Shelf Res., Vol. 27, pp. 832-853, 2007.

8) Kubota, M : Continental Shelf Waves off the Fukushima Coast Part 3. Numerical Experiments., J. Oceanogr. Soc. Japan, Vol. 38, pp. 323$330,1985$.

9) 内山雄介, 山西环文, 津旨大輔, 宮澤泰正, 石井倫生 : 福島第一原発からの放射性核種の初期分散に及ぼす沿岸 ジェットとメソスケール渦の影響, 土木学会論文集 B2 (海岸工学)，Vol.69, No.2, pp.I_1051-I_1055, 2013.

(2016.3.16 受付)

\title{
COASTAL DISPERSAL OF RIVER-DERIVED SUSPENDED RADIONUCLIDES DUE TO A FLOOD EVENT AROUND THE MOUTH OF NIIDA RIVER, FUKUSHIMA
}

\author{
Takafumi YAMANISHI, Yusuke UCHIYAMA, Toshiki IWASAKI, \\ Yasuyuki SHIMIZU, Daisuke TSUMUNE, Kazuhiro MISUMI and Yuichi ONDA
}

We examine oceanic dispersal of the iRIC-Nays2DH-evaluated sediment and suspended ${ }^{137} \mathrm{Cs}$ influxes from Niida River, Fukushima, with a particular attention to the first flood event in late May of 2011 after the Fukushima nuclear accident. Alongshore suspended ${ }^{137}$ Cs transport occurs assymetrically, comprising storm-driven southward transport confined in the shallow area due to shoreward Ekman transport associated with strong northerly wind, followed by northwestward widespread transport under mild southerly wind condition. About $70 \%$ of the Niida River-derived suspended ${ }^{137} \mathrm{Cs}$ remains near the mouth for 20 days after the flood event. Nevertheless, our model results as well as an observation suggest that the area is dominated by erosion as for high bed shear stress all the time, thus suspended radionuclides are redistributed to dissipate away in long term. 